\section{Adequacy of prenatal care, diagnosis and treatment of syphilis in pregnancy: a study with open data from Brazilian state capitals}

\author{
Adequação de atendimento pré-natal, diagnóstico \\ e tratamento da sífilis gestacional: um estudo \\ com dados abertos de capitais brasileiras
}

\author{
Adecuación de la atención prenatal, diagnóstico \\ y tratamiento de la sífilis en el embarazo: \\ un estudio con datos abiertos en siete \\ capitales brasileñas
}

\author{
Adele Schwartz Benzaken 1 \\ Gerson Fernando Mendes Pereira 2 \\ Alessandro Ricardo Caruso da Cunha 2 \\ Flavia Moreno Alves de Souza 2 \\ Valéria Saraceni 3
}

doi: 10.1590/0102-311X00057219

\begin{abstract}
To assess the adequacy of prenatal care offered in the Brazilian capital cities and the diagnosis of gestational syphilis through public data from health information systems. The modified Kotelchuck index for adequacy of prenatal care was built using Brazilian Information System on Live Births (SINASC) data. Data on gestational syphilis, congenital syphilis, estimated population coverage by the Family Health Strategy (FHS), the Municipal Human Development Index (MHDI) and data from National Program for Access and Quality Improvement in Primary Care (PMAQ-AB) were accessed in public sites. The profile of pregnant women associated with inadequate care was assessed by logistic regression. In total, 685,286 births were analyzed. Only 2.3\% of women did not attend prenatal appointments. The mean adequacy was 79.7\%. No correlation was found between adequacy of prenatal care and FHS coverage $(p=0.172)$, but a positive correlation was found with the MHDI ( $p$ $<0.001$ ). Inadequacy of prenatal care was associated with age below 20 years old, schooling less than 4 years, non-white skin color and not having a partner. Among the congenital syphilis cases, $17.2 \%$ of mothers did not attend prenatal c are. Gestational syphilis more often affected vulnerable women, including a higher proportion of adolescents, women with low schooling, and women of non-white color. The PMAQ-AB showed a median availability of $27.3 \%$ for syphilis rapid tests, $67.7 \%$ for benzathine penicillin, and $86.7 \%$ for benzathine penicillin administration by health teams. The use of public data showed a low adequacy of prenatal care in Brazilian capitals, denoting insufficient quality for the diagnosis and treatment of gestational syphilis, despite the availability of supplies. Continuous monitoring can be carried out using public data, indicating to local strategies to eliminate congenital syphilis.
\end{abstract}

Prenatal Care; Syphilys; Congenital Syphilis; Health Systems

\author{
Correspondence \\ V. Saraceni \\ Coordenação de Doenças Transmissíveis, Secretaria Municipal \\ de Saúde. \\ Rua Afonso Cavalcanti 455, sala 809, Rio de Janeiro, RJ \\ 20211-901, Brasil. \\ valsaraceni@gmail.com \\ 1 Fundação de Medicina Tropical Doutor Heitor Vieira \\ Dourado, Manaus, Brasil. \\ 2 Departamento de Vigilância, Prevenção e Controle das \\ Infecções Sexualmente Transmissíveis do HIV/Aids e das \\ Hepatites Virais, Ministério da Saúde, Brasília, Brasil. \\ 3 Coordenação de Doenças Transmissíveis, Secretaria Municipal \\ de Saúde, Rio de Janeiro, Brasil.
}




\section{Introduction}

Assessing the status of health condition is the initial step to organize the planning and management of a specific health problem within a population, to assess the degree of implementation of a public health policy or the need for public policy review 1 .

The global burden of sexually transmitted infections is high and diverge between regions of the world 2 . The detection rate of acquired syphilis is increasing in Brazil, and this trend is confirmed by the increase of gestational syphilis 3 .

The differences among the Brazilian capitals can be assessed by the Brazilian Information System for Notifiable Diseases (SINAN), the Brazilian Information System on Live Births (SINASC), the Brazilian Mortality Information System (SIM), and the Brazilian Hospital Information System (SIH), generating data to create strategies for data qualification and to establish monitoring of indicators. The structured investigation of fetal and infant deaths due to congenital syphilis adds evidence to this disease scenario 4 . Syphilis has long been known to be a cause of fetal loss, and it remains a public health problem 5,6 .

The intervening factors in the current situation of gestational and congenital syphilis probably derive from the access to and capacity of prenatal care 7 , as well as the coverage of primary health care in the Brazilian state capitals. Maternal and infant mortalities are associated with the inadequacy of prenatal care 8,9. In Brazil, the high incidence of congenital syphilis is added to these negative outcomes 3 . A composite index - developed by Kessner and modified by Kotelchuck 10, based on the month of entry in prenatal care and the total number of medical appointments as well as the gestational age at which the medical appointments occurred - enables the comparison among the state capital cities. In the ordinance establishing the Stork Network [Rede Cegonha], the Brazilian Ministry of Health defined adequate prenatal care as that initiated before the 12th week of pregnancy, with at least 6 appointments distributed by pregnancy's quarters 11 .

Analysis of the use of supplies distributed by the federal government and those purchased by municipalities, as well as the structure of the service network, adds information that may support interventions to achieve the goal of eliminating congenital syphilis 12 . The shortage of penicillin in the international market in 2014 led to the acquisition of this drug by the Brazilian Ministry of Health, to minimize the impact of the lack of the only medicine that prevents congenital syphilis 13 .

The Brazilian National Basic Health Care Policy (PNAB) provides the evaluation of health teams and care offered to users. The Ordinance GM/MS n. 1,654 of July 19, 2011, implemented the National Program for Access and Quality Improvement in Primary Care (PMAQ-AB) in the Family Health Strategy (FHS) with questionnaires to be applied to health teams, health professionals and managers, and also performance indicators to be measured 14 .

Prenatal care is essential for gestational syphilis diagnosis and congenital syphilis prevention 15 . Therefore, knowing the adequacy of prenatal care, measured by the Kotelchuck index, modified to include the lack of prenatal care $16,17,18$ in the Brazilian state capital cities, provides a background to be linked with gestational and congenital syphilis data.

The availability of open data at the municipal level in Brazil enables analyses that can help examine current public policies and their interactions, monitoring the current situation and pointing to the necessity of changing the course of some actions as well ass to new strategies. The objective of this study was to describe and compare the characteristics of women and the adequacy of prenatal care in the Brazilian state capital cities, with a focus on gestational syphilis diagnosis and treatment as a cornerstone strategy for congenital syphilis elimination.

\section{Methods}

The SINASC database of capital cities was obtained from the Brazilian Health Informatics Department (DATASUS; http://datasus.saude.gov.br/informacoes-de-saude/servicos2/transferencia-de-arquivos) for 2016. The modified Kotelchuck index was built based on the number of prenatal medical appointments and the month that prenatal care began. The criteria for constructing the composite indicator categories were as follows: (i) Without prenatal care: did not attend any appointment; (ii) 
Inadequate: began prenatal care after the forth month or attended $<50 \%$ of the medical appointments expected for the gestational age; (iii) Intermediate: began prenatal care by the forth month and attended $50 \%$ to $79 \%$ of medical appointments expected for the gestational age; (iv) Appropriate: began prenatal care by the forth month and attended $80 \%$ to $109 \%$ of the medical appointments expected for the gestational age; and (v) Intensive: began prenatal care by the forth month and attended $\geq 110 \%$ of medical appointments expected for the gestational age.

Information about gestational and congenital syphilis was collected from the Syphilis Epidemiological Bulletin -20183 of the Secretariat for Health Surveillance, Brazilian Ministry of Health, and from the database Indicators and Basic Data of Syphilis in Brazilian Municipalities (http://indicadoressifi lis.aids.gov.br/) for the year 2016. The source for those indicators was SINAN. The data obtained was entered in an Microsoft Excel spreadsheet (https://products.office.com/).

The Department of Primary Care (DAB), Brazilian Ministry of Health, provides the estimated population coverage of the FHS by competence, from which data were obtained for December 2016 (https://egestorab.saude.gov.br/paginas/acessoPublico/relatorios/relHistoricoCoberturaAB.xhtml). The Municipal Human Development Index (MHDI) was obtained from the Human Development Atlas in Brazil (http://www.atlasbrasil.org.br/2013/pt/download/) to use as a summary measure of inequality among the Brazilian state capitals.

The correlation of the adequacy of prenatal care and FHS coverage, gestational syphilis detection rate and MHDI were assessed by Spearman's correlation test, as well as the correlation between gestational syphilis rate and MHDI. Also, the correlation of benzathine penicillin administration in pregnant women at primary care units, congenital syphilis incidence rate, distribution of syphilis rapid test, and benzathine penicillin availability was assessed using the same test.

The information of the PMAQ-AB second cycle (2014) was obtained at the DAB website (http:// aps.saude.gov.br/ape/pmaq/ciclo2/), with the extraction of data concerning both gestational and congenital syphilis prevention and control guidelines.

The Kotelchuck index was presented by capital. Subsequently, a second variable, the inadequacy of prenatal care ("yes/no") was derived to identify factors associated with inadequacy of prenatal care by logistic regression, where "no" was calculated as the sum of the "adequate" and "intensive" categories and "yes" as the sum of intermediary, inadequate and no prenatal care. The outcome variable was inadequacy of prenatal care. The independent variables were age, race, marital status, schooling, quantity of births and type of pregnancy. Those with a p-value $<0.20$ were included in a stepwise multivariate regression. To remain in the final model, a p-value $<0.05$ was used. The data were tabulated in Stata v.11.0 (https://www.stata.com).

The Kiviat diagram was used to compare maternal variables, such as, age below 20 years and less than 4 years of schooling, in SINASC, and data extracted from SINAN gestational syphilis, and SINAN congenital syphilis ${ }^{3}$. Two aspects of vulnerability related to public health were available in those databases: one at the individual level (age at diagnosis) and one at social level (years of schooling) 19.

Data regarding fetal death was obtained from SIM (TABNET/DATASUS; http://www2.datasus. gov.br/DATASUS/index.php?area=02) and the Syphilis Epidemiological Bulletin 3.

There was no submission to the Research Ethics Committee since data were publicly available and were analyzed in groups without subject identification, in accordance with Resolution n. 466/2012 of the Brazilian National Health Council.

\section{Results}

In 2016, 685,286 live births were recorded in SINASC among the 27 Brazilian state capitals. We excluded the following cases: those in which both variables regarding prenatal appointments (consultations, categorized as 0; 1-3; 4-6; and 7 and more; consprenant, as ordinal numbers from 0 to i) were missing $(n=4,501)$; those with a numeric answer to appointments as a categorical variable but without the number of appointments $(\mathrm{n}=35)$; and those with a numeric answer to appointments but without the month prenatal care began $(n=21,655)$. Those women were slightly younger than those remaining in the analysis (median age: 26 vs. 27 years old) and with a higher proportion of lower schooling (3.2\% vs. $1.4 \%)$. Thus, 659,095 live births were analyzed. 
The average number of appointments per woman was $7.9(\mathrm{SD}=3.2)$ and the median was 8.0. Only $2.3 \%$ of women did not attend prenatal appointments. Table 1 depicts the distribution of the modified Kotelchuck index for each Brazilian capital cities. Porto Velho stood out with $13.3 \%$ without prenatal appointments, the remaining cities ranged between $0.5 \%$ and $8.5 \%$. Among those who received prenatal care, 9.6\% started after the 16th week, which is considered late. In accordance with the Stork Network, $79.3 \%$ of women start prenatal care by the 12 th week. The median maternal age was 27 years old (interquartile range: 22-33). Regarding the adequacy of prenatal care (adequate and intensive), the mean value for the 27 cities was 79.7\% (SD = 7.3), varying from Curitiba (92.1\%) to Macapá (59.7\%).

No correlation was found between the adequacy of prenatal care and the FHS coverage $(\mathrm{p}=0.172)$, nor between the adequacy of prenatal care and gestational syphilis detection rate $(\mathrm{p}=$ 0.524). The correlation prenatal care of the adequacy with the MHDI resulted in a positive correlation, as the Brazilian capital cities with higher MHDI showed higher adequacy $(\mathrm{p}<0.001)$ (Figure 1). Moreover, MHDI had no correlation with gestational syphilis detection rate $(\mathrm{p}=0.355)$.

Table 2 shows the results of both crude and adjusted logistic regression seeking for factors associated with prenatal care inadequacy. The bivariate logistic regression showed that the odds of having

Table 1

Proportional distribution of the modified Kotelchuck index for adequacy of prenatal care in the Brazilian state capital cities, 2016.

\begin{tabular}{|c|c|c|c|c|c|}
\hline City & $\begin{array}{l}\text { Did not receive } \\
\text { prenatal care }\end{array}$ & $\begin{array}{c}\text { Inadequate } \\
\text { prenatal care }\end{array}$ & $\begin{array}{l}\text { Intermediary } \\
\text { prenatal care }\end{array}$ & $\begin{array}{c}\text { Adequate prenatal } \\
\text { care }\end{array}$ & $\begin{array}{c}\text { Intensive prenatal } \\
\text { care }\end{array}$ \\
\hline Porto Velho & 13.3 & 15.3 & 5.5 & 16.9 & 49.0 \\
\hline Rio Branco & 2.7 & 19.8 & 6.5 & 17.4 & 53.6 \\
\hline Manaus & 2.5 & 17.2 & 9.0 & 22.5 & 48.8 \\
\hline Boa Vista & 2.5 & 17.2 & 7.3 & 17.2 & 55.8 \\
\hline Belém & 3.9 & 13.3 & 6.4 & 16.7 & 59.7 \\
\hline Macapá & 3.2 & 22.8 & 14.3 & 19.7 & 40.0 \\
\hline Palmas & 0.4 & 8.2 & 4.0 & 14.9 & 72.5 \\
\hline São Luís & 1.1 & 13.0 & 11.6 & 24.1 & 50.2 \\
\hline Teresina & 5.6 & 9.3 & 5.5 & 15.3 & 64.3 \\
\hline Fortaleza & 5.6 & 11.6 & 5.8 & 17.7 & 59.3 \\
\hline Natal & 1.1 & 12.8 & 6.8 & 18.0 & 61.3 \\
\hline João Pessoa & 1.8 & 10.4 & 6.5 & 16.0 & 65.2 \\
\hline Recife & 1.8 & 13.5 & 6.1 & 17.6 & 61.0 \\
\hline Maceió & 1.9 & 13.0 & 8.3 & 22.9 & 53.9 \\
\hline Aracaju & 0.8 & 10.8 & 10.2 & 20.3 & 57.9 \\
\hline Salvador & 4.9 & 13.5 & 5.7 & 18.8 & 57.1 \\
\hline Belo Horizonte & 0.4 & 6.3 & 3.2 & 11.1 & 78.8 \\
\hline Vitória & 0.5 & 7.4 & 3.4 & 9.6 & 79.1 \\
\hline Rio de Janeiro & 1.5 & 9.3 & 2.3 & 9.1 & 77.8 \\
\hline São Paulo & 1.0 & 8.0 & 3.2 & 10.3 & 77.5 \\
\hline Curitiba & 0.5 & 6.1 & 1.3 & 3.5 & 88.6 \\
\hline Florianópolis & 1.2 & 9.2 & 3.0 & 11.0 & 75.6 \\
\hline Porto Alegre & 1.7 & 10.9 & 3.5 & 9.2 & 74.7 \\
\hline Campo Grande & 1.3 & 8.7 & 7.1 & 16.6 & 66.3 \\
\hline Cuiabá & 0.5 & 13.2 & 4.7 & 14.3 & 67.3 \\
\hline Goiânia & 8.5 & 8.9 & 3.3 & 12.3 & 67.0 \\
\hline Brasília & 2.3 & 10.0 & 3.4 & 10.2 & 74.1 \\
\hline Total & 2.3 & 10.5 & 4.7 & 13.5 & 69.0 \\
\hline
\end{tabular}

Source: Brazilian Information System on Live Births (SINASC), 2016, available at the Brazilian Health Informatics Department (DATASUS; http://datasus. saude.gov.br/informacoes-de-saude/servicos2/transferencia-de-arquivos). 


\section{Figure 1}

Correlation between adequacy of prenatal care and Municipal Human Development Index (MHDI) in Brazilian state capital cities, 2016.

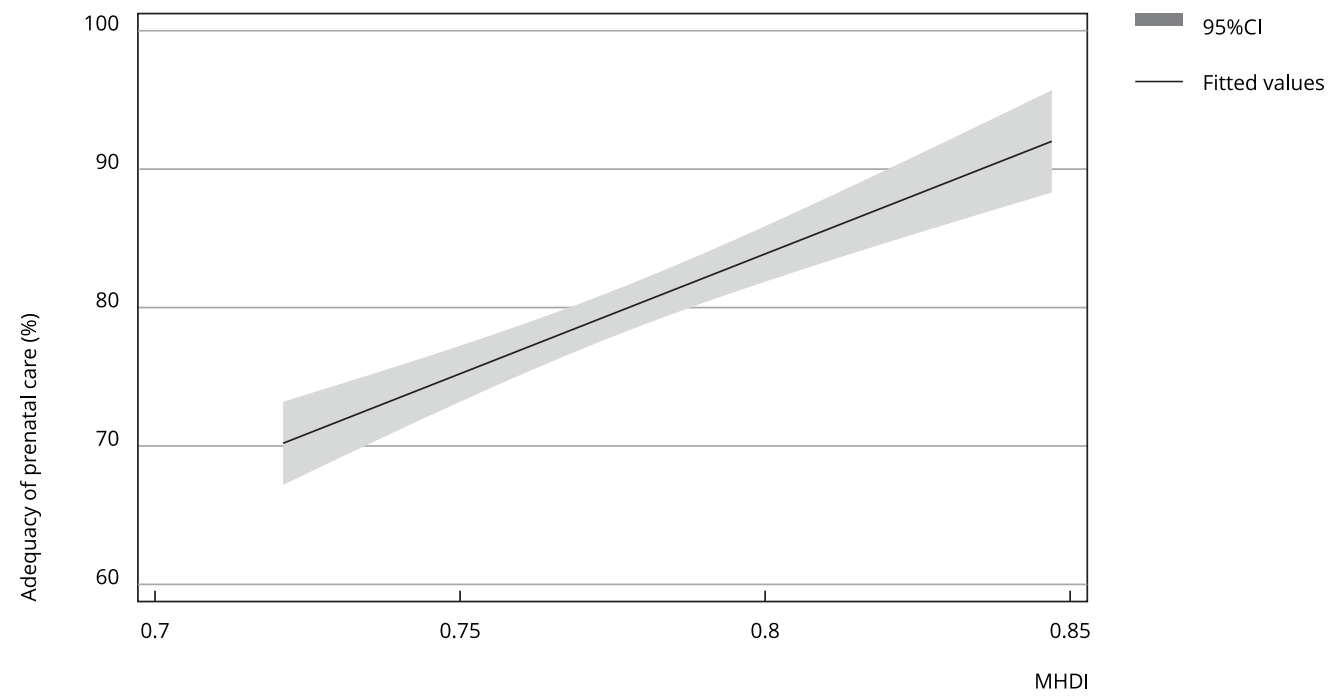

95\% Cl: 95\% confidence interval.

Source: Brazilian Information System on Live Births (SINASC), 2016, available at the Brazilian Health Informatics

Department (DATASUS; http://datasus.saude.gov.br/informacoes-de-saude/servicos2/transferencia-de-arquivos); Human Development Atlas in Brazil (http://www.atlasbrasil.org.br/2013/pt/download/).

Table 2

Crude and adjusted odds ratios (OR) for maternal characteristics associated with inadequacy of prenatal care in the Brazilian state capital cities, 2016.

\begin{tabular}{|c|c|c|c|c|c|c|}
\hline Characteristics & Crude OR & $95 \% \mathrm{Cl}$ & p-value & Adjusted OR & $95 \% \mathrm{Cl}$ & p-value \\
\hline \multicolumn{7}{|l|}{ Age group (years) } \\
\hline$\geq 20$ & 1.00 & & & 1.00 & & \\
\hline$<20$ & 2.10 & $2.07-2.13$ & $<0.001$ & 2.53 & $2.48-2.58$ & $<0.001$ \\
\hline \multicolumn{7}{|l|}{ Color } \\
\hline White & 1.00 & & & 1.00 & & \\
\hline Other & 2.38 & $2.34-2.42$ & $<0.001$ & 1.93 & $1.89-1.96$ & $<0.001$ \\
\hline \multicolumn{7}{|l|}{ Marital situation } \\
\hline With a partner & 1.00 & & & 1.00 & & \\
\hline Without a partner & 1.96 & $1.93-1.98$ & $<0.001$ & 1.70 & $1.68-1.73$ & $<0.001$ \\
\hline \multicolumn{7}{|l|}{ Schooling (years) } \\
\hline$\geq 4$ & 1.00 & & & 1.00 & & \\
\hline$<4$ & 2.76 & $2.64-2.88$ & $<0.001$ & 2.06 & $1.97-2.16$ & $<0.001$ \\
\hline \multicolumn{7}{|l|}{ Quantity of births } \\
\hline None & 1.00 & & & 1.00 & & \\
\hline 1 or more & 1.90 & $1.87-1.92$ & $<0.001$ & 2.39 & $2.35-2.43$ & $<0.001$ \\
\hline
\end{tabular}

95\%Cl: 95\% confidence interval.

Source: Brazilian Information System on Live Births (SINASC), 2016, available at the Brazilian Health Informatics

Department (DATASUS; http://datasus.saude.gov.br/informacoes-de-saude/servicos2/transferencia-de-arquivos). 
inadequate prenatal care for mothers younger than 20 years old were 2.1 times higher; the odds were also higher for non-white mothers (2.4 times), women without a partner (1.9 times), women with less than 4 years of schooling (2.8 times) and women with 1 or more living children (1.9 times). The same variables remained in the multivariate model.

The vulnerability of pregnant women with syphilis was higher than that of population represented in the SINASC data, with high variability among the Brazilian capital cities (Figure 2). The Kiviat diagram helps to visualize that the proportion of adolescent mothers among those with syphilis in SINAN was two times higher than the SINASC record, while the proportion of women with less than 4 years of schooling in this group of subjects with syphilis was much higher.

Data from the Syphilis Epidemiological Bulletin 3 revealed that the lack of prenatal care attendance represented $17.2 \%$ of mothers with congenital syphilis cases, higher than the SINAN as a whole (2.3\%). Some capital cities of the Northeast (Teresina, Fortaleza, Natal, Recife, Maceió, and Aracaju) and Porto Alegre (South Region) present higher congenital syphilis incidence rates than gestational syphilis detection rates, which may reflect a lack of detection and inadequate treatment.

Table 3 presents some of the PMAQ-AB outcomes of interest by Brazilian state capital city, the estimated population coverage of the FHS, the gestational syphilis detection rate and the congenital syphilis incidence rate. Analyzing PMAQ-AB questions with a direct impact on gestational syphilis diagnosis and treatment, it was seen that the proportion of primary health care units (UBS) that reported "always" having availability for the syphilis rapid test (SRT) ranged between 1\% in Curitiba and $97.1 \%$ in Campo Grande, with a median of 27.3\% (interquartile range - IQR: 9.4\%-67.2\%). In relation to the availability of the drug benzathine penicillin to syphilis treatment of pregnant women, the answer "yes" ranged between 0\% in Natal and 100\% in Vitória, with a median of 67.7\% (IQR: 12.5\%-90.9\%). Regarding the availability of a sufficient supply quantity of the drug mentioned above, among the cities with drug availability, the median was 95\% (IQR: 87.5\%-100.0\%). The question about intramuscular administration of injectable medication by the health team had the answer "yes" ranging between $74.6 \%$ in Belém and 100\% in 14 other capitals. Specifically, for intramuscular administration of benzathine penicillin, the answer "yes" ranged between 0\% in João Pessoa and 100\% in Porto Velho, Rio Branco, Aracaju, Vitória, and Campo Grande, with a median of 86.7\% (IQR: 42.9\%-99.7\%).

Assessing the relationship between the administration of benzathine penicillin in pregnant women in primary care and the congenital syphilis incidence rate in the capitals, it was observed that three of the five capitals with the highest congenital syphilis rates (Porto Alegre, Recife, Fortaleza, Rio de Janeiro, and Teresina) had percentages of intramuscular administration of benzathine penicillin ranging between $80 \%$ and $100 \%$. The distribution of those two variables did not show a correlation $(\mathrm{p}=0.51)$.

The availability of benzathine penicillin could had influenced on the use of SRT in primary care, since SRT should be performed and followed by treatment initiation in pregnant women with positive results as soon as possible. Again, the distribution of SRT and benzathine penicillin availability showed no correlation $(\mathrm{p}=0.08)$. The median availability of the VDRL test for prenatal care was $99.6 \%$.

Data on fetal deaths due to congenital syphilis are also useful in building the burden of gestational syphilis and childbirth and can be obtained from the SIM. Recife, Palmas, Florianópolis and Rio de Janeiro had the highest proportions of congenital syphilis causing fetal death, ranging between $6.2 \%$ and $17.2 \%$, among Brazilian state capital (data not shown). Six state capital cities did not report any fetal death due to congenital syphilis in the mortality system in 2016. However, only three of those cities did not report any syphilitic stillbirths to SINAN in the same year, according to the Syphilis Epidemiological Bulletin 3. 


\section{Figure 2}

Distribution of maternal age below 20 years old and maternal schooling level less than 4 years in the Brazilian

Information System on Live Births (SINASC) and Syphilis Epidemiological Bulletin - 2018. Brazilian state capital cities, 2016.

2a) Adolescent mothers $<20$ years
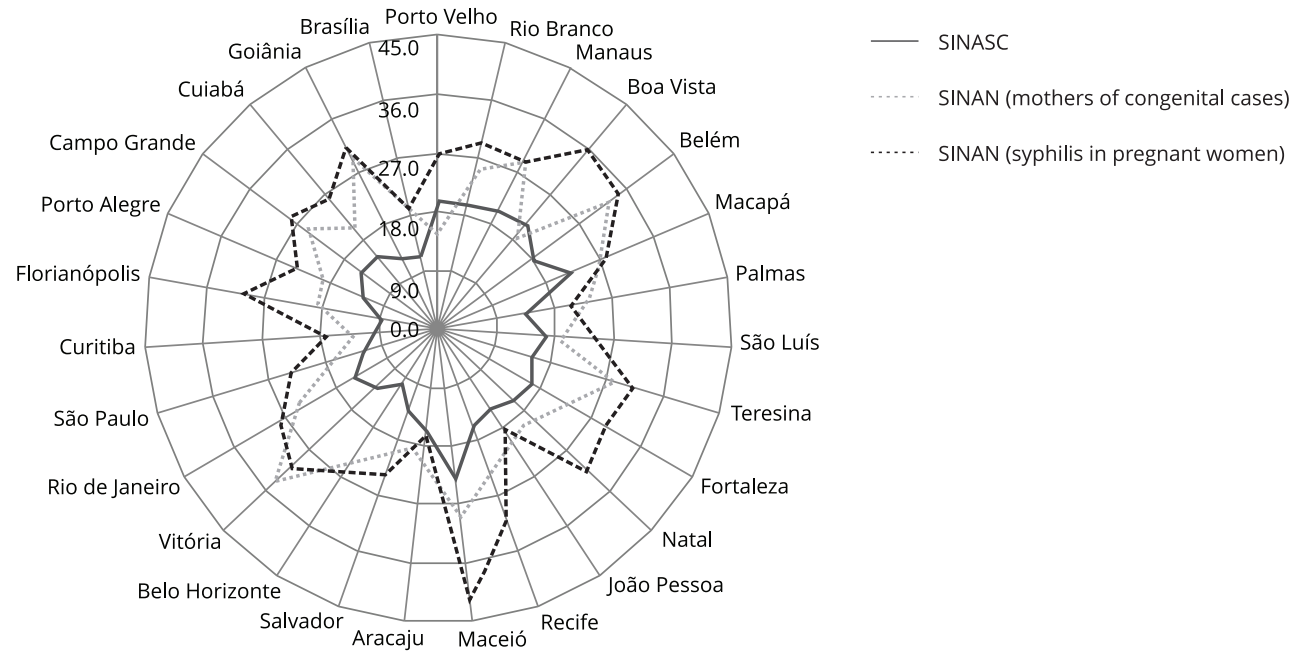

2b) Schooling $<4$ years

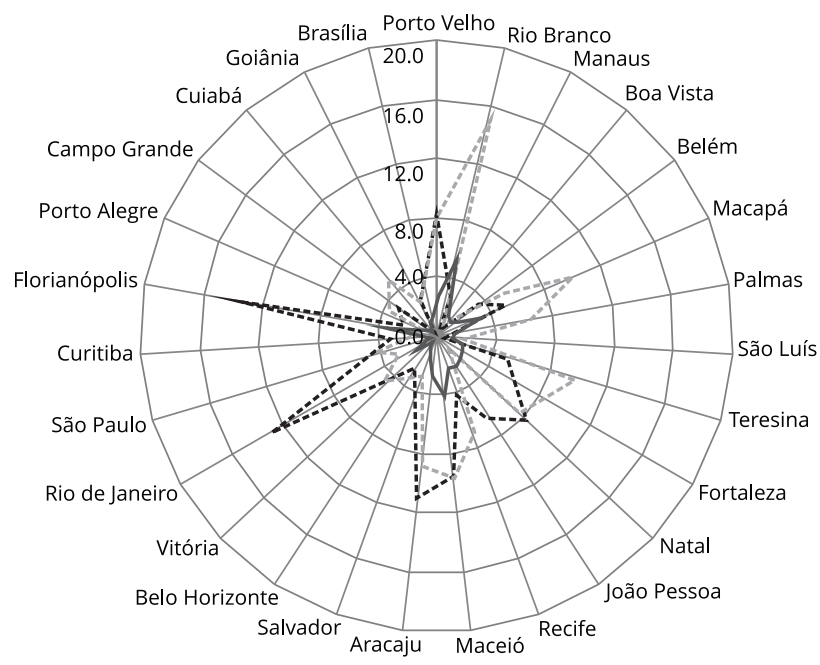

- SINASC

-..... SINAN (mothers of congenital cases)

...... SINAN (syphilis in pregnant women)

SINAN: Brazilian Information System for Notifiable Diseases

Source: SINASC, 2016, available at the Brazilian Health Informatics Department (DATASUS; http://datasus.saude.gov.br/ informacoes-de-saude/servicos2/transferencia-de-arquivos); Syphilis Epidemiological Bulletin - 20183. 
Table 3

Information regarding the diagnosis and treatment of syphilis available on National Program for Access and Quality Improvement in Primary Care (PMAQ-AB) - 2nd cycle, Family Health Strategy (FHS) coverage, gestational syphilis detection rate and congenital syphilis incidence per Brazilian state capital city, 2014-2015.

\begin{tabular}{|c|c|c|c|c|c|c|c|c|}
\hline City & $\begin{array}{l}\text { Primary } \\
\text { care units } \\
\text { (n) }\end{array}$ & $\begin{array}{c}\text { SRT always } \\
\text { available (\%) }\end{array}$ & $\begin{array}{c}\text { Benzathine } \\
\text { penicillin } \\
\text { available (\%) }\end{array}$ & $\begin{array}{l}\text { If yes, drug } \\
\text { available in } \\
\text { sufficient } \\
\text { quantity (\%) }\end{array}$ & $\begin{array}{l}\text { Health team applies } \\
\text { intramuscular } \\
\text { administration } \\
\text { benzathine } \\
\text { penicillin (\%) }\end{array}$ & $\begin{array}{c}\text { Estimated } \\
\text { population } \\
\text { coverage of } \\
\text { FHS (\%) }\end{array}$ & $\begin{array}{l}\text { Syphilis } \\
\text { detection } \\
\text { rate in } \\
\text { pregnant } \\
\text { women }\end{array}$ & $\begin{array}{l}\text { Congenital } \\
\text { syphilis } \\
\text { incidence } \\
\text { rate }\end{array}$ \\
\hline Porto Velho & 17 & 94.1 & 82.4 & 92.9 & 100.0 & 57.3 & 12.2 & 6.9 \\
\hline Rio Branco & 22 & 36.4 & 90.9 & 95.0 & 100.0 & 57.8 & 32.7 & 2.9 \\
\hline Manaus & 142 & 2.1 & 4.9 & 100.0 & 27.9 & 33.1 & 24.9 & 10.1 \\
\hline Boa Vista & 23 & 69.6 & 4.4 & 100.0 & 45.5 & 59.3 & 15.0 & 1.6 \\
\hline Belém & 44 & 9.1 & 11.4 & 60.0 & 42.9 & 24.3 & 12.5 & 8.0 \\
\hline Macapá & 25 & 40.0 & 84.0 & 81.0 & 94.7 & 64.1 & 11.3 & 6.2 \\
\hline Palmas & 32 & 9.4 & 12.5 & 100.0 & 25.0 & 84.5 & 9.2 & 5.8 \\
\hline São Luís & 36 & 2.8 & 55.6 & 100.0 & 67.4 & 35.7 & 12.4 & 7.5 \\
\hline Teresina & 9 & 22.2 & 88.9 & 100.0 & 86.7 & 100.0 & 9.5 & 14.5 \\
\hline Fortaleza & 54 & 18.5 & 51.9 & 96.4 & 36.6 & 51.6 & 8.3 & 18.2 \\
\hline Natal & 34 & 29.4 & 0.0 & 0.0 & 5.3 & 46.8 & 6.8 & 12.1 \\
\hline João Pessoa & 98 & 19.4 & 2.0 & 50.0 & 0.0 & 83.1 & 0.9 & 0.8 \\
\hline Recife & 124 & 14.5 & 62.9 & 91.0 & 74.3 & 52.3 & 7.4 & 21.2 \\
\hline Maceió & 19 & 47.4 & 84.2 & 87.5 & 58.3 & 29.5 & 7.8 & 9.8 \\
\hline Aracaju & 31 & 80.7 & 67.7 & 85.7 & 100.0 & 75.8 & 6.3 & 8.3 \\
\hline Salvador & 55 & 49.1 & 52.7 & 93.1 & 87.5 & 27.2 & 21.3 & 15.9 \\
\hline Belo & 146 & 49.3 & 98.6 & 95.1 & 98.2 & 80.2 & 15.1 & 9.3 \\
\hline \multicolumn{9}{|l|}{ Horizonte } \\
\hline Vitória & 22 & 27.3 & 100.0 & 100.0 & 100.0 & 73.3 & 34.1 & 13.9 \\
\hline Rio de Janeiro & 173 & 94.8 & 94.8 & 99.4 & 99.7 & 44.1 & 35.0 & 16.4 \\
\hline São Paulo & 269 & 3.4 & 90.7 & 93.0 & 99.7 & 31.6 & 19.1 & 6.3 \\
\hline Curitiba & 101 & 1.0 & 82.2 & 90.4 & 98.0 & 42.6 & 18.4 & 5.8 \\
\hline Florianópolis & 45 & 11.1 & 97.8 & 100.0 & 98.0 & 99.4 & 22.5 & 9.5 \\
\hline Porto Alegre & 133 & 84.2 & 94.0 & 88.0 & 98.7 & 41.6 & 22.9 & 29.3 \\
\hline Campo & 50 & 97.1 & 94.1 & 96.9 & 100.0 & 34.7 & 27.6 & 9.5 \\
\hline \multicolumn{9}{|l|}{ Grande } \\
\hline Cuiabá & 59 & 16.0 & 4.0 & 50.0 & 9.7 & 37.1 & 4.3 & 3.7 \\
\hline Goiânia & 59 & 6.8 & 37.3 & 100.0 & 76.0 & 43.2 & 9.6 & 4.1 \\
\hline Brasília & 64 & 67.2 & 54.7 & 100.0 & 73.1 & 30.2 & 7.2 & 4.7 \\
\hline
\end{tabular}

SRT: syphilis rapid test.

Source: PMAQ-AB - 2nd cycle available on Department of Primary Care (DAB), Brazilian Ministry of Health; Syphilis Epidemiological Bulletin - 20183.

\section{Discussion}

The adequacy of prenatal care measured by the modified Kotelchuck index showed disparity among the Brazilian state capital cities, with a mean of $82.4 \%$. In the municipality of Rio de Janeiro, the same index showed an adequacy of $61.4 \%$ between 1999 and 2001 16. In a metropolitan area in the Northeast, the value was $66.1 \%$ in 2005 14. By using the Humanization of Prenatal and Birth Program (PNHP) criteria, a study in Vitória pointed to an inadequate prenatal care being delivered in 2010/2011 20.

The proportion of women without any prenatal care was low (2.3\%) in SINASC, and 9.6\% started prenatal care later than expected. In the Birth in Brazil study, conducted between 2011 and 2012, the 
factors associated with late start were the difficulty of pregnancy diagnosis, personal characteristics and impediments to access the care 21.

In this study, inadequacy of prenatal care was associated with women younger than 20 years and with less than 4 years of schooling. These two factors were assessed to compare the general population of pregnant women (SINASC data) with the pregnant women infected with syphilis; higher levels were found in the latter, characterizing a greater vulnerability associated with syphilis. According to the same study, only $1.3 \%$ of women referred no prenatal care, the adequacy of prenatal care was significantly lower for black adolescent women, for those with low schooling level, women belonging to social classes D and E, women without work, and women without a partner 22.

The proportion of mothers with congenital syphilis cases that reported no prenatal care among all the state capital cities reached $17.2 \%$, seven times higher than in the general SINASC population. The vulnerability of women receiving inadequate prenatal care and, even worse, when infected with syphilis, shows the need of a closer approach on this population, in order to compensate its vulnerability. Other factors associated with vulnerability, such as poverty, violence, and inequality may be present in different degrees among Brazilian cities, prompting the need of strategies designed to reach those women 23,24 . The FHS could play a positive role in this situation, as long as health teams are inside the poorer communities. However, the estimated FHS coverage of the population did not correlate with the adequacy of prenatal care in this study. In a previous study, also with an ecological design, the FHS coverage was not related to the gestational syphilis diagnosis 25 .

In an ecological approach, only the MHDI was correlated with the adequacy of prenatal care, showing that this composite index, based on income, education, and longevity, better discriminates the differences among the cities. MHDI is a composite index that does not explain inequalities within the population. Cities as Porto Alegre, which has a high adequacy (83.9\%) shows a high syphilis detection rate (22.9) and an even higher congenital syphilis rate (29.3), probably related to a small fraction of the population with a more vulnerable situation and a greater exposure to syphilis. Teixeira et al. 26 associated the higher rates of gestational and congenital syphilis in Porto Alegre to a greater coverage of FHS in the region between 2001 and 2012.

Brazil has universal access to health care. Nonetheless, the Brazilian Unified National Health System (SUS) is used by the poorer. Being able to discuss quality of delivered prenatal care would need to include both public and private sectors. In the Birth in Brazil study, $28.8 \%$ of the women, ranging between $11.9 \%$ in the Northern region and $32.6 \%$ in the Southern region, sought prenatal care in the private sector 22 . However, this study was unable to achieve this goal of looking at the public and private sector separately with the use of secondary data. Nonetheless, the data gave us an insight of an association of lower education with both inadequate prenatal care and syphilis, which would be taken care of the public sector. Therefore, the efforts in Brazil should be aimed at not only achieving $100 \%$ coverage of prenatal care but also increasing its quality with new strategies to identify women at increased risk and placing them in good care 27 . Domingues \& Leal 28 found an increased risk of vertical syphilis transmission in women with incomplete basic education $(\mathrm{OR}=16.02)$ and a higher proportion of lack of prenatal care attendance in their congenital syphilis group.

Following the pregnancy care guidelines should result in better syphilis management 11 , thereby reducing the congenital syphilis occurrence. Looking at Brazilian Ministry of Health strategies to increase the quality of syphilis care during pregnancy, such as the acquisition and distribution of SRT by the Department of STI, HIV/AIDS and Viral Hepatitis (DIAHV) to the 27 states, PMAQ-AB data revealed that the median availability of SRT was $27.3 \%$ in 2014 , when $3,156,510$ tests were distributed (http://www.aids.gov.br/pt-br/pub/2018/20112017-distribuicao-de-testes-rapidos-para-sifilis). From the same source, the median availability of benzathine penicillin, which has been lacking in the international and national markets, was $67.7 \%$. Therefore, having access to test and treatment are the cornerstones of syphilis control in pregnancy, and despite tests and drugs were available, not all health teams reported the same practice in PMAQ-AB. Logistical issues or local decisions may be relevant in this situation, hindering the elimination of congenital syphilis The intramuscular administration of benzathine penicillin was also heterogeneous at the UBS participating in the PMAQ-AB. On the other hand, the reported availability of the VDRL test was high in the capital cities. In a national survey, the request for the first VDRL reached $89.1 \%$ in 2011-2012, with the second test later in pregnancy being reported in only $41.1 \%$ of the cases 28 . 
The availability of benzathine penicillin did not directly influence the SRT use, local primary care protocols and the FHS coverage may be influencing the outcomes. For example, the SRT was less used in Curitiba (1\% of positive responses), which has long-established local prenatal care guidelines (http://www.saude.curitiba.pr.gov.br/index.php/programas/mae-curitibana) with good outcomes for both mother and child.

One more factor to consider is that syphilis affects the fetus directly 5 and the proportional fetal mortality due to congenital syphilis must be kept below $2 \%$, according to the World Health Organization (WHO) 29. In our study, we found four cities with values higher than $2 \%$, noticing the negative outcomes of gestational syphilis. However, such results may be related to the quality of fetal death investigation on those cities, yielding more cases due to gestational syphilis. The underreporting of infant and fetal deaths due to congenital syphilis is an issue that has been persisting in Brazil 30,31, although the investigation of those deaths plays an important role in health surveillance policies 4 .

The quality of prenatal care offered by SUS, covering more than $80 \%$ of Brazilian pregnant women, can be assessed by the available information systems, as demonstrated in this study. The use of the PMAQ-AB results added relevant information on the utilization of basic syphilis supplies by FHS teams. Moreover, it was possible to portray the scenario of primary care, regarding the distribution of supplies directly through DIAHV to the states, in order to increase the diagnosis with SRT and to enable adequate treatment with benzathine penicillin at the primary care level 32 . Studies focused on the impact of the FHS on pregnancy outcomes are needed, keeping in mind that FHS is a set of multiple interventions aiming the population health. A study on the effect of FHS on tuberculosis treatment success is a good model to evaluate the interventions on gestational syphilis 33 .

This study has limitations due to the use of secondary data, including the possibility of an ecological fallacy when aggregate data is analyzed. The Brazilian health information systems are gathering better data, with SINASC coverage estimated in $98 \%$ in 201534 . Therefore, the variability in point estimates is somewhat reduced as data gains robustness. Although we have used data from a single year in this study, they sources contain enough information to enable the establishment of trends, supporting some conclusions of this paper. The variety of public sources of information helped us to demonstrate a pattern of vulnerability of women with gestational syphilis, low adequacy of prenatal care in some Brazilian capital cities, and the practices of health teams facing gestational syphilis. Providing a good prenatal care is essential to diagnose and treat gestational syphilis, avoiding congenital syphilis 15 . As far as we know, this is the first study to assess the health situation regarding the adequacy of prenatal care and syphilis diagnosis in pregnancy using this kind of data. This information may be shared with state and municipal managers to assist in health planning, as set out in the Brazilian Ministry of Health strategic agenda to eliminate congenital syphilis 35 . It is important to add that a health survey aimed at answering similar questions would require a much larger staff and higher funding.

\section{Conclusions}

Although it was not possible to establish a correlation between prenatal adequacy and the rate of detection of gestational syphilis, the data showed a similarity between those women with inadequate prenatal and those with gestational syphilis, and enabled us to assess how health teams act in the care of the vulnerable population.

The use of public data gathered in the information systems and other sources for the analysis of health situation showed a low adequacy of prenatal care in the Brazilian capital cities, with high heterogeneity of performance, demonstrating that the quality of gestational syphilis diagnosis and treatment is insufficient, despite the availability of supplies. A direct relationship with adequacy of prenatal care could not be demonstrated, but the profile of women receiving inadequate care and those with syphilis were similar, indicating to a vulnerable population that deserves better care.

Thus, considering the amount of information available, both as individual data or aggregated indicators on public websites, some of then with the investigation of congenital syphilis cases and deaths being done in the cities, continuous monitoring can be executed with moderate effort, indicating local strategies that can be used to eliminate congenital syphilis. 


\section{Contributors}

A. S. Benzaken and G. F. M. Pereira contributed to the study design and conception and critical review of the final version. A. R. C. Cunha contributed to the writing of the paper and critical review of the final version. F. M. A. Souza contributed to the writing of the paper, data analysis, and critical review of the final version. V. Saraceni contributed to the writing of the paper, data analysis, collection and structuring, and critical review of the final version.

\section{Additional informations}

ORCID: Adele Schwartz Benzaken (0000-00025789-0695); Gerson Fernando Mendes Pereira (0000-0001-8886-1662); Alessandro Ricardo Caruso da Cunha (0000-0001-5441-1006); Flavia Moreno Alves de Souza (0000-0002-2882-2861); Valéria Saraceni (0000-0001-7360-6490).

\section{References}

1. Hartz ZMA, editor. Avaliação em saúde: dos modelos conceituais à prática na análise da implantação de programas online. Rio de Janeiro: Editora Fiocruz; 1997.

2. Newman L, Rowley J, Vander Hoorn S, Wijesooriya NS, Unemo M, Low N, et al. Global estimates of the prevalence and incidence of four curable sexually transmitted infections in 2012 based on systematic review and global reporting. PLoS One 2015; 10:e0143304.

3. Departamento de Vigilância, Prevenção e Controle das Infecções Sexualmente Transmissíveis, do HIV/Aids e das Hepatites Virais, Secretaria de Vigilância em Saúde, Ministério da Saúde. Boletim Epidemiológico de Sífilis 2018. Brasília: Ministério da Saúde; 2018.

4. Secretaria de Vigilância em Saúde; Secretaria de Atenção à Saúde, Ministério da Saúde. Manual de vigilância do óbito infantil e fetal e do Comitê de Prevenção do Óbito Infantil e Fetal. Brasília: Ministério da Saúde; 2009.

5. Watts TE, Larsen SA, Brown ST. A case-control study of stillbirths at a teaching hospital in Zambia, 1979-80: serological investigations for selected infectious agents. Bull World Health Organ 1984; 62:803-8.

6. Newman L, Kamb M, Hawkes S, Gomez G, Say L, Seuc A, et al. Global estimates of syphilis in pregnancy and associated adverse outcomes: analysis of multinational antenatal surveillance data. PLoS Med 2013; 10:e1001396.

7. Guerra AB, Guerra LM, Probst LF, Gondinho BVC, Ambrosano GMB, Melo EA, et al. Can the primary health care model affect the determinants of neonatal, post-neonatal and maternal mortality? A study from Brazil. BMC Health Serv Res 2019; 19:133.

8. Leite RMB, Araújo TVB, Albuquerque RM, Andrade ARS, Duarte Neto PJ. Fatores de risco para mortalidade materna em área urbana do Nordeste do Brasil. Cad Saúde Pública 2011; 27:1977-85

9. Maia LTS, Souza WV, Mendes ACG. Diferenciais nos fatores de risco para a mortalidade infantil em cinco cidades brasileiras: um estudo de caso-controle com base no SIM e no SINASC. Cad Saúde Pública 2012; 28:2163-76.

10. Kotelchuck M. An evaluation of the Kessner Adequacy of Prenatal Care Index and a proposed Adequacy of Prenatal Care Utilization Index. Am J Public Health 1994; 84:1414-20.

11. Ministério da Saúde. Portaria no 1.459 , de 24 de junho de 2011. Institui, no âmbito do Sistema Único de Saúde - SUS - a Rede Cegonha. Diário Oficial da União 2011; 27 jun.

12. Arnesen L, Serruya S, Duran P. Gestational syphilis and stillbirth in the Americas: a systematic review and meta-analysis. Rev Panam Salud Pública 2015; 37:422-9.

13. Secretaria de Vigilância em Saúde; Secretaria de Atenção à Saúde, Ministério da Saúde. Nota Informativa no 006/2016/GAB/DDAHV/SVS/ MS. Brasília: Ministério da Saúde; 2016. 
14. Departamento de Atenção Básica, Secretaria de Atenção à Saúde, Ministério da Saúde. Nota metodológica da certificação das equipes de atenção básica participantes do Programa Nacional de Melhoria do Acesso e da Qualidade da Atenção. Brasília: Ministério da Saúde; 2015.

15. Wendel GD, Sheffield JS, Hollier LM, Hill JB, Ramsey PS, Sanchez PJ. Treatment of syphilis in pregnancy and prevention of congenital syphilis. Clin Infect Dis 2002; 35 Suppl 2:S200-9.

16. Leal MC, Gama SGN, Ratto KMN, Cunha CB. Uso do índice de Kotelchuck modificado na avaliação da assistência pré-natal e sua relação com as características maternas e o peso do recém-nascido no Município do Rio de Janeiro. Cad Saúde Pública 2004; 20 Suppl 1:S63-72.

17. Ribeiro ER, Guimarães AM, Bettiol H, Lima DD, Almeida ML, de Souza L, et al. Risk factors for inadequate prenatal care use in the metropolitan area of Aracaju, Northeast Brazil. BMC Pregnancy Childbirth 2009; 9:31.

18. Bernardes AC, da Silva RA, Coimbra LC, Alves MT, Queiroz RC, Batista RF, et al. Inadequate prenatal care utilization and associated factors in São Luís, Brazil. BMC Pregnancy Childbirth 2014; 14:266.

19. Ayres JRCM, França Júnior I, Calazans GJ, Saletti Filho HC. O conceito de vulnerabilidade e as práticas de saúde: novas perspectivas e desafios. In: Czeresnia D, Freitas CM, editors. Promoção da saúde: conceitos, reflexões, tendências. Rio de Janeiro: Editora Fiocruz; 2009. p. 121-43.

20. Polgliane RB, Leal MC, Amorim MH, Zandonade E, dos Santos Neto ET. Adaptation of the process of prenatal care in accordance with criteria established by the Humanization of Prenatal and Birth Program and the World Health Organization. Ciênc Saúde Colet 2014; 19:1999-2010.

21. Viellas EF, Domingues RMSM, Dias MAB, Gama SGN, Theme Filha MM, Costa JV, et al. Assistência pré-natal no Brasil. Cad Saúde Pública 2014; 30 Suppl 1:S85-100.

22. Domingues RM, Viellas EF, Dias MA, Torres JA, Theme-Filha MM, Gama SG, et al. Adequacy of prenatal care according to maternal characteristics in Brazil. Rev Panam Salud Pública 2015; 37:140-7.

23. DiOrio D, Kroeger K, Ross A. Social vulnerability in congenital syphilis case mothers: qualitative assessment of cases in Indiana, 2014 to 2016. Sex Transm Dis 2018; 45:447-51.

24. Benzaken AS, Sabidó M, Brito I, Bermúdez XPD, Benzaken NS, Galbán E, et al. HIV and syphilis in the context of community vulnerability among indigenous people in the Brazilian Amazon. Int J Equity Health 2017; 16:92.
25. Saraceni V, Miranda AE. Relação entre a cobertura da Estratégia Saúde da Família e o diagnóstico de sífilis na gestação e sífilis congênita. Cad Saúde Pública 2012; 28:490-6.

26. Teixeira LO, Belarmino V, Gonçalves CV, Mendoza-Sassi RA. Temporal trend and spatial distribution of congenital syphilis in the state of Rio Grande do Sul between 2001 and 2012. Ciênc Saúde Colet 2018; 23:2587-97.

27. Cooper JM, Michelow IC, Wozniak PS, Sánchez PJ. In time: the persistence of congenital syphilis in Brazil - more progress needed! Rev Paul Pediatr 2016; 34:251-3.

28. Domingues RMSM, Leal MC. Incidência de sífilis congênita e fatores associados à transmissão vertical da sífilis: dados do estudo Nascer no Brasil. Cad Saúde Pública 2016; 32:e00082415.

29. Kamb ML, Newman LM, Riley PL, Mark J, Hawkes SJ, Malik T, et al. A road map for the global elimination of congenital syphilis. Obstet Gynecol Int 2010; 2010:312798.

30. Saraceni V, Guimarães MHFS, Theme Filha MM, Leal MC. Mortalidade perinatal por sífilis congênita: indicador da qualidade da atenção à mulher e à criança. Cad Saúde Pública 2005; 21:1244-50.

31. Cardoso AR, Araújo MA, Andrade RF, Saraceni V, Miranda AE, Dourado MI. Underreporting of congenital syphilis as a cause of fetal and infant deaths in Northeastern Brazil. PLoS One 2016; 11:e0167255.

32. Secretaria de Vigilância em Saúde; Secretaria de Atenção à Saúde, Ministério da Saúde. Caderno de Boas Práticas. O uso da penicilina na atenção primária para a prevenção da sífilis congênita. Brasília: Ministério da Saúde; 2016.

33. Durovni B, Saraceni V, Puppin MS, Tassinari W, Cruz OG, Cavalcante S, et al. The impact of the Brazilian Family Health Strategy and the conditional cash transfer on tuberculosis treatment outcomes in Rio de Janeiro: an individual-level analysis of secondary data. J Public Health (Oxf) 2018; 40:e359-66.

34. Secretaria de Vigilância em Saúde, Ministério da Saúde. Saúde Brasil 2017: uma análise da situação de saúde e os desafios para o alcance dos objetivos e desenvolvimento sustentável. Brasília: Ministério da Saúde; 2018.

35. Secretaria de Vigilância em Saúde; Secretaria de Atenção à Saúde, Ministério da Saúde. Agenda de ações estratégicas para redução da sífilis congênita no Brasil. Brasília: Ministério da Saúde; 2016. 


\section{Resumo}

O estudo buscou avaliar a adequação do atendimento pré-natal oferecido nas capitais brasileiras e o diagnóstico da sífilis gestacional através de dados públicos dos sistemas de informação de saúde. Foi construído o indicador de Kotelchuck modificado para adequação do atendimento pré-natal, usando dados do Sistema de Informações sobre Nascidos Vivos (SINASC). Foram acessados em sites públicos os dados sobre sífilis gestacional, sífilis congênita, estimativa da cobertura populacional pela Estratégia Saúde da Família (ESF), Índice de Desenvolvimento Humano (IDH) municipal e dados do Programa Nacional de Melhoria do Acesso e da Qualidade da Atenção Básica (PMAQ-AB). O perfil das gestantes associado ao atendimento inadequado foi avaliado com base na regressão logística. Foram analisados um total de 685.286 nascimentos. Apenas 2,3\% das mulheres não receberam atendimento pré-natal. A taxa média de adequação foi de 79,7\%. Não foi encontrada correlação entre a adequação do pré-natal e a cobertura pela ESF ( $p=0,172)$, mas houve correlação com o IDH municipal $(p<0,001)$. A inadequação da assistência pré-natal mostrou associação com a idade $<20$ anos, escolaridade < 4 anos, raça/cor não-branca e situação conjugal sem companheiro. Entre os casos de sífilis congênita, 17,2\% das mães não haviam recebido atendimento pré-natal, e a sífilis gestacional afetava mais as gestantes vulneráveis, incluindo uma proporção maior de adolescentes, mulheres com baixa escolaridade e mulheres não brancas. O PMAQ-AB mostrou uma disponibilidade mediana de $27,3 \%$ de testes rápidos para sífilis, $67,7 \%$ para penicilina benzatina e $86,7 \%$ para administração de penicilina benzatina pela equipe de saúde. O uso de dados públicos revelou baixa adequação do atendimento pré-natal nas capitais brasileiras, denotando qualidade insuficiente para o diagnóstico e tratamento da sífilis gestacional, apesar da disponibilidade de insumos. O monitoramento contínuo pode ser realizado com o uso de dados públicos, indicando estratégias locais para eliminar a sífilis congênita.

Cuidado Pré-Natal; Sífilis; Sífilis Congênita; Sistemas de Saúde

\section{Resumen}

El objetivo de este trabajo ha sido evaluar la adecuación de la atención prenatal que se ofreció en capitales brasileñas, y el diagnóstico de sífilis gestacional, mediante datos públicos de los sistemas de información de salud. El indicador modificado de Kotelchuck para la adecuación de la atención prenatal se construyó usando datos del Sistema de Información sobre Nacidos Vivos (SINASC). La información sobre sifilis gestacional, sifilis congénita, así como la cobertura de población estimada por la Estrategia Salud de Familia (ESF), Índice de Desarrollo Humano (IDH) municipal y datos del Programa Nacional para el Acceso Mejorado y Calidad de la Atención Básica (PMAQ-AB) se recabaron de sitios web públicos. El perfil de las mujeres embarazadas asociado con el cuidado inadecuado fue evaluado mediante regresión logistica. En total, se analizaron 685.286 nacimientos. Solamente un 2,3\% de las mujeres no atendieron a citas prenatales. La adecuación media fue de un 79,7\%. No se encontró correlación entre la adecuación del cuidado prenatal y la cobertura de la ESF $(p=0,172)$, pero se encontró una correlación positiva con el MHDI $(p<0,001)$. La inadecuación del cuidado prenatal estuvo asociada con una edad < 20 años, escolaridad < 4 años, raza no blanca y no tener pareja. Entre los casos de sífilis congénita, un 17,2\% de las madres no asistieron a la atención prenatal. La sífilis gestacional afectó más a menudo a las mujeres vulnerables, incluyendo una más alta proporción de adolescentes, mujeres con baja escolaridad, y mujeres de color no blanco. La PMAQ-AB mostró un promedio de disponibilidad de un 27,3\%, en el caso de test rápidos de sífilis, un 67,7\% para la penicilina benzatínica, y un 86,7\% para la administración penicilina benzatínica por equipos de salud. El uso de los datos públicos mostró una baja adecuación del cuidado prenatal en capitales brasileñas, denotando una insuficiente calidad para el diagnóstico y tratamiento de la sifilis gestacional, a pesar de la disponibilidad de suministros. La supervisión continua se puede llevar a cabo usando datos públicos, apuntando a estrategias locales para eliminar la sífilis congénita.

Atención Prenatal; Sífilis; Sífilis Congénita; Sistemas de Salud
Submitted on 25/Mar/2019

Final version resubmitted on 05/Jul/2019

Approved on 09/Jul/2019 